\title{
Aspects of the Paternity of Metropolitan Iosif Naniescu's Liturgical Chant (1818-1902)
}

\author{
CODRUT - DUMITRU SCURTU \\ Theological Orthodox Seminary "Saint Nicholas” Râmnicu-Vâlcea \\ ROMÂNIA*
}

\begin{abstract}
The Romanian Orthodox Church in the $19^{\text {th }}$ century and the first half of the $20^{\text {th }}$ century had a valuable generation of hierarchs protopsalts, composers, translators and promoters of the psaltic music of the Byzantine tradition. From this exceptional generation, Iosif Naniescu is the most valuable composer and interpreter of the $19^{\text {th }}$ century psaltic music. By his rich musical work, Metropolitan Iosif stands out as a reference point for the composition and translation of Greek psaltic chanting. Thanks to the original compositions and translations from the old music notation system, Iosif Naniescu may be included among the promoters of the Christian music notation system in our country alongside Macarie the Monk (with whom he would collaborate), Anton Pann (with whom he bound a close friendship between 1839-1854), and Dimitrie Suceveanu (whom he promoted as a protopsalter of Moldavia). The quality of his performance is highlighted by the countless written testimonies over time. Iosif Naniescu shows a special talent and zeal in his widespread work of over 100 musical manuscripts (stored in our country and in the Holy Mountain of Athos); he is also acknowledged for the Psalms of Time, which he copied in anthologies besides his own chants. Therefore, the present article comes to assert the origins of his chants and pays tribute to classical music of Byzantine tradition.
\end{abstract}

Keywords: Metropolitan, Protopsalt, Paternity, Lyturgical Chant, Iosif Naniescu.

\section{Introduction}

The Romanian Orthodox Church in the 19th century and the first half of the 20th century had a valuable generation of hierarchs protopsalts, composers, translators and promoters of psaltic music of Byzantine tradition. Among the bishops who were entrusted the pastoral care of the Argeș Diocese we mention Ghenadie Țeposu-Argeșiu (1813-1877), Gherasim Timuș (1848-1911), Iosif Naniescu (1818-1902) (Scurtu, 2011, pp. 253-284), and Evghenie HumulescuPiteşteanul (1870-1931) (Scurtu, 2007, pp. 281-291). From this exceptional generation, Iosif Naniescu is the most esteemed composer and interpreter of the $19^{\text {th }}$ century psaltic music. By his rich musical work, Metropolitan Iosif stands out as a reference point for the composition and translation of Greek psaltic chanting. Thanks to the original compositions and translations from the old music notation system, Iosif Naniescu may be included among the promoters

\footnotetext{
*dumitru_codrut@yahoo.com
} 
of the Christian music notation system in our country alongside Macarie the Monk (with whom he would collaborate), Anton Pann (with whom he enjoyed a close friendship between 1939-1854), and Dimitrie Suceveanu (whom he promoted as a protopsalter of Moldavia).

\section{The musical work}

The quality of a good performer is highlighted by the countless written testimonies over time. Iosif Naniescu shows a special talent and zeal in his widespread work of over 100 musical manuscripts (stored in our country and in the Holy Mountain of Athos); he is also acknowledged for the Psalms of Time, which he copied in anthologies besides his own chants.

\subsection{Manuscripts from Romania}

The musical compositions signed by Metropolitan Iosif Naniescu can be found in over 76 manuscripts in Romania, in 28 libraries, such as: The Library of the Romanian Academy - B.A.R. - 17 manuscripts - Rom. ms. 3931, Rom. ms. 1743, Rom. ms. 4399, Rom. ms. 4402, Rom. ms. 4426, Rom. ms. 4427, Rom. ms. 4434, Rom. ms. 4013, Rom. ms. 5108, Rom. ms. 4382, Rom. ms. 4605, Rom. ms. 2343, Rom. ms. 3809, Rom. ms. 4249, Rom. ms. 4344, Rom. ms. 1191 and greek. ms. 835; The Library of the Holy Synod ${ }^{1}-$ B.S.S. - 9 manuscripts - ms rom. I-18, ms rom. I-17, ms rom. - gr I-54, ms rom. I-76, ms. Rom. II-7, ms-rom II-34, ms-rom III-29, ms. rom 97205/2011 and ms. rom. 97206/2011 (Patrașcu, 2010, pp. 57-60, 62-66, 7174, 75-82, 87-88, 204-210, 233-284 și 221-223; Barbu-Bucur\&Catrina, 2013, pp. 142-144); the Library of the Union of Composers and Musicologists ${ }^{2}-$ B.U.C.M. - 4 manuscripts - Rom. ms. 4635, Rom. ms. 4658, ms. 4659 and ms. 4686 (Secară, 2006, pp.50, 61-68, 68-69 și 93-97); the Library of the Stavropoleos Monastery ${ }^{3}$ - Bucharest - B.M.St. - 4 manuscripts - ms. no 85M, ms. no 92M, ms. no 4941 and ms. no 9628; Mihai Eminescu Central University Library from Iasi ${ }^{4}$ - B.C.U.M.E. - 4 manuscripts - ms., No. III79, ms., No. I-56, ms., no. II-34 and Rom. ms. II-71 (Isăroiu, 2008, pp. 194-

\footnotetext{
${ }^{1}$ Byzantinologist Alexie Al. Buzera mentions it in his catalogue as the host manuscript of the musical work of Metropolitan Iosif Naniescu and Rom. ms. B.S.S. II-67. Cf. Buzera, 1999, p. 174.

${ }^{2}$ Byzantinologist Alexie Buzera mentions it in this library as a host manuscript of the musical work of Iosif Naniescu, and ms. 4684, ms. 4687, ms. II-71 and ms. II-34. Cf. Buzera, 1999, pp. 126, 181, 129.

${ }^{3}$ Byzantinologist Al. Alexie Buzera presents a non-quota manuscript, including, among other things, songs by Iosif Naniescu, belonging to the Library of the Stavropoleos Monastery in Bucharest. Cf. Buzera, 1999, p. 132.

${ }^{4}$ In the book of this library, Constantin C. Angelescu recalled the existence of a manuscript with the musical work of Iosif Naniescu in one of his studies having the quotation II-34 Angelescu, 1982, "Metropolitan Iosif Naniescu” in Mitropolia Moldovei și Sucevei, LVIII, 1-2, January-February, p. 68, footnote no. 85.
} 
209; see also Buzera, Al. A., Three manuscripts... 1999, pp. 70-71, see Bucescu, 2002, p. 111); Râmnicu - Vâlcea Archdiocese Library - B.A.Rm.Vl. - 3 manuscripts: grek. - Rom., no., 6649, file no. 493, and ms. Rom., 7515/197 (Gavrilă, 2010, pp. 351-360); The Library of the Archdiocese of Argeş - B.A.A. - 3 manuscripts - rom. no. 981, rom. no. 982, and rom. no. 983; Nicolae Iorga Library from Ploiesti - B.N.I.P. - 3 manuscripts: rom. no., D. II., 2599, ms. rom. no. D. I. 1737, and romanian no., D. II., 2645; Buzău Archdiocese Museum - Mz.A.B. - 3 manuscripts: ms. no. 2797, ms. no. 2957 and ms. no. 4063 (Moise, 2004, pp. 128-129); The Library of the Metropolitan Church of Moldavia and Bucovina - B.M.M.B. - 4 manuscripts: Rom. ms., no. $340^{5}$, Rom. ms. no. $105,{ }^{6}$ Rom. ms. no. 11, and Rom. ms. no. 44; Oltenia Museum from Craiova - Mz.O. - 2 manuscripts: Rom. ms. no. 84 and Rom. ms. no. 86 (Buzera, 1999, p. 190); The Library of Parish Rediu Tătar-Iasi - B.P.R.T. - 2 manuscripts: Rom. ms. no. 1, Notebook 1 and Rom. ms. no. 1, Notebook 2 (Nastasă, 2010, pp. 502-507); The Library of the Tapalari-Iași Church - B.B.T.I. - 1 ms: Rom. ms. no. 72 (Bucescu, 2009, pp. 211-214); The Library of the Ciolanu-Buzău Monastery - B.M.C.B. - 2 manuscripts: Rom. ms. no. 1605 II C.1 and Rom. ms. no. 1051 (Moise, 2004, pp. 148-154); the Romanian National Library - B.Nț.R. 2 manuscripts: Rom. ms. no. 4269 and Rom. ms. no. 10567 (Bucescu, 2009, pp. 518, 527); Rev. Ion Oprea's Private Library, Vălenii de Munte - Prahova - B.P.I.O. 1 ms: ms. without quotation (Barbu-Bucur\&Catrina, 2013, pp. 76-78); the Library of Văratec Monastery - B.M.V. - 1 ms: ms. no. 207/B7 (Bucescu\&Catrina\&Barnea\&Dănilă, 2010, pp. 322-323); the Library of Neamt Monastery - B.M.N. - 1ms: Rom. ms. no. 15 (Bucescu\&Catrina\&Barnea\&Dănilă, 2010, vol. II, pp. 145-147); the Library of Sinaia Monastery in Prahova - B.M.S.P. - 1 ms: Rom. ms. no. 37 (Harbuzaru, 2012, pp. 139-144); the Library of Cheia Monastery in Prahova - B.M.C.P. - 1 ms: without quotation; National Archives in Vâlcea Country - the National Archives of Vâlcea Country - 1ms: Rom. ms. no. 80 (See also Neacşu, 2006, pp. 408-412.); the Library of The Theology Seminary in Buzău - B.S.T.B. - 1 ms: ms. without quotation (Moise, 2004, p. 129); the Private Library of Prior Partenie Apetrei from Neamț - B.P.A.P. - 1 ms: ms. no. 1 (Nastasă, 2010, pp. 507-510.); the Library of Tarcău-Neamț Hermitage - B.S.T.N. - 1ms: ms. no.

\footnotetext{
${ }^{5}$ Manuscript no. 340 from the content Archimandrite I. Grădinaru B.M.M.B. with the musical work of Metropolitan Iosif Naniescu is presented in Gaşpar, I., 1982, "A Manuscript of Church Songs”, in Mitropolia Moldovei și Sucevei, LVIII, 1-2, pp. 69-74.

${ }^{6}$ Manuscript no. 105 is presented in Vasile "Iosif Naniescu...”, II, pp. 105-110. Another host manuscript of the musical work of Joseph Naniescu is presented briefly with quotation no. 11 in Buzera, 1999, Musical Culture ..., p. 183; see also Bucescu, F., 2009, Psaltic Song in the Moldavian manuscripts of the 19th century. A Guide to Psaltic Manuscripts-Moldavia, the $19^{\text {th }}$ century, vol. II, Iaşi: Artes, pp. 113-132.
} 
1 (Nastasă, 2010, pp. 513-516); the Central University Library in Bucharest B.C.U. - 1 ms: ms.nr. 10862 (Buzera, 1999, p. 185); Titus Moisescu Private Library in Bucharest - B.P.T.M. - 1ms: Rom. ms. no. 4 (Ionescu, 2003, pp. 273-274); Private Library of Archdeacon Sebastian Barbu-Bucur in Bucharest - B.P.S.B. - 1 ms: ms. without quotation and Private Alexie Buzera Library in Craiova - B.P.A.B. - 1ms: ms. no. 4 (Buzera, 1999, p. 200).

\subsection{Manuscripts from the Holy Mountain of Athos}

More than 23 musical manuscripts are housed in the Holy Mountain of Athos, among other songs and compositions by Iosif Naniescu, spread in 10 libraries, such as: The Prodromu-Athos Hermitage Library - B.S.P. - 10 manuscripts: Rom. ms. no. 6/93, Rom. ms. no. 10/4, Rom. ms. no. 24/54, Rom. ms. no. 77/17, Rom. ms. no. 94/99, Rom. ms. no. 97/74, Rom. ms. no. 112/67, Rom. ms. no. 123/102, Rom. ms. no. 129/29 and Rom. ms. no. 137/43 (Barbu-Bucur, 2000, pp. 36, 41, 65, 165, 196, 199, 218, 234, 241, 256.); the Private Library Gheorghe (Gamaliil) Boboc Hieroschehermit B.P.G.B. - 3 manuscripts: ms. 35/III, ms. without quotation inv, ms. without quotation (Vasile, 2007, pp. 259-268, 268); the Saint John the Theologian Romanian Hermitage in Cucuvinu - Provata - B.S.I.C. - 2 manuscripts: without quotation (Vasile, 2007, p. 160); the Lacu-Athos Hermitage Library - B.S.L. - 2 manuscripts: Rom. ms. no. 2 and Rom. ms. no. 21 (Barbu-Bucur, 2000, pp. 283-310.); the Stavronikita Monastery Library - B.M.S. - 1 ms: ms. no. 23 (Vasile, 2008, pp. 40-43); The Great Lavra Library in Athos - B.M.L. - 1 ms: Rom. ms. no. 4 (Barbu-Bucur, 2000, p. 275.); The Hermitage Library of the Assumption of the Holy Virgin Mary B.A.M.D. - 1 ms: Rom. ms. no. 2 (Barbu-Bucur, 2000, p. 322); The Library of The Hermitage of Saint George at Colciu-Vatoped - B.S.G.C. - 1 ms: Rom. ms. no. 5 (Barbu-Bucur, 2000, p. 344); The Library of the Hermitage of Saint John the Baptist - B.S.I.B.V. - 1 ms: Rom. ms. no. 4 (Barbu-Bucur, 2000, p. 371) and The Library of Saint Ipaty Hermitage at Vatoped - B.S.I.V. - 1ms: Rom. ms. no. 17 (Barbu-Bucur, 2000, p. 409).

\section{The paternity of metropolitan Iosif Naniescu's liturgical chant (1818- 1902)}

As one of the most important personalities of the Romanian Orthodox Church, Iosif Naniescu left a rich musical work, containing original works, translations from the Greek language, revisions (of some chants written by Hieromonk Macarie and Anton Pann, o.n.), and chants written after his death, with the mention "as it was performed by Metropolitan Iosif Naniescu".

According to manuscript notes, on March 24, 1836, Buzău, the Hierodeacon Iosif wrote “Aghioasele” Mode VIII (Great Answers, o.n.) which, 
even after 180 years, are sung by the whole Romanian Orthodoxy with the same beauty and freshness.

Regarding the roots of these songs, we may try some observations. It is very interesting that Iosif Naniescu indirectly mentions that the manuscripts of these answers would not belong to him, but are adapted in the Buzău Seminary School, in 1836, after the Greek ones.

Here we can notice two aspects. One would be that these answers had circulated in a Greek version since ancient times and Iosif translated them into his mother tongue, encouraged by the Romanian trend of translating church chanting. The second aspect would be that these answers were written by Iosif Naniescu at a time when, ecclesiastically speaking, the Romanian Countries were under Greek domination, and Iosif had to present them as "translated", not "composed", which meant as a precaution gesture of the future metropolitan.

Not detecting the original Greek version might also be because of their original circulation in oral form exclusively. The Mediaeval method of memorizing a whole repertoire of songs, which encouraged the learning of melodic formulas (theses) with great ease, is known to us (Gheorghiță, 2012, p. 392).

Gherasim Safrin, the Romanian Bishop, printed a "Collection of Church Songs" in Bucharest, at the Printing House of Church Books in 1809, and published these responses on 50-51 pages; he also offered the information that Iosif Naniescu, “...as a Metropolitan, has changed them between 1875-1876”. This is remarkable, because Iosif translated faithfully the Greek chants, often using the word "just" to guarantee this. Knowing the scrupulosity and fidelity of his Greek translations, Iosif Naniescu allowed himself to change them after some time when his beliefs and musical inspiration were likely to have reached maturity. Thus, we may notice and analyze his vision of translation (or, why not, his composition?) from the age of his only 18 years old (1836) as compared to that of his 58 years old (1876), after 40 years of compositional experience. In 1999, the Byzantine chorus "Psalmodia" of the National Music University of Bucharest recorded these overly beautiful Responses on an audio tape under the conductor Archdeacon Sebastian Barbu-Bucur, in the "Electrecord" studio in Bucharest, along with other beautiful chants selected from the "Liturgy of Saint John Chrysostom".

We find these songs in several manuscripts in Romania and also at the Holy Mountain of Athos. They are some of Iosif Naniescu's most popular chants. In Romania we find them in: B.A.R. Rom. ms. 3931 f. 12 (verse 24, repeated, Mode VIII ni "We Praise Thee"); B.AR. Rom. ms. 1743 f. 1; B.A.R. Rom. ms. 4434 f. 14; B.A.R. Rom. ms. 4382 f. 54v; B.A.R. Rom. ms. 2343 f. 101 (p. 196); B.A.R. Rom. ms. 4344 f. 48; B.A.R. Rom. ms. 4402 f. 30 (only ”We Praise Thee” n. n.); B.S.S. Rom. ms. II-34 f.74v; B.S.S. Rom. ms. no. D. 
97206/ 2011 p. 35; B.M.St. ms. no. 92, p. 116; B.M.St. ms. no. 4941 f. 10; B.A.A. ms. no. M. 982 p. 208; B.A.A. ms. no. M. 983 f. 115v; B.N.I.P. Rom. ms. D. I 1737 pp. 245, 255, 259, 264, 266, 381; B.N.I.P. ms. D. II. 2645 f. 93v; B.P.R.T. ms. no. 1 Notebook 1; f. 20v-21v; B.M.V. ms. 207/B7; f. 97v-31; B.M.N. Rom. ms. no. 15; f. 76-77v; B.M.S.P. Rom. ms. no. 37; f. 226v; B.C.U.M.E. Rom. ms. no. III-79; f. 15v; B.M.M.B. ms. 105 f. 98; B.S.T.N. ms. no. 1; f. 90-94; B.B.T.I., ms. no. 72, f. 230 and B.P.S.B., ms. without quotation pp. $150-152$.

We identify these Great Responses in Mode 8 at the Holy Mountain of Athos in: B.S.P. Rom. ms. 77/17 f. 179; B.S.P. Rom. ms. 94/99 f. 1; B.S.P. Rom. ms. $97 / 74$ f. 365-366; B.S.P. Rom. ms. 112/67 f. 31; B.S.P. Rom. ms. 123/102 f. 54; B.P.G.B. ms. no. 35/III f. 59v.- 60; B.P.G.B. ms. no. 2 pp. 135137; B.S.I.C. ms. without quotation f. 14-15v; B.S.L. Rom. ms. no. 2 f. 205v; B.S.L. Rom. ms. no. 21 f. 138v; B.M.L. Rom. ms. no. 4 f. 103; B.A.M.D. Rom. ms. no. 2 f. 179; and B.S.G.C. Rom. ms. no. 5 f. (see also Barbu-Bucur, 2000, pp. 167, 197, 203, 218, 234, 91, 284, 311, 276, 324, 344; see also Vasile, 2007, pp. 160, 265).

An anthology engraved by one of Metropolitan Iosif's disciples (Ghiţă Ionescu-Rom. ms., BAR No. 4249) holds only $80 \%$ of the Metropolitan's chants. The manuscript contains, besides other original songs, "Christ is risen" on Mode 5 (the $2^{\text {nd }}$ form of the Mode), at page 188, along with the mention: “At Easter Mode V pa, by Archimandrite Iosif Naniescu...”. We find this song published in Neagu Ionescu's new edition of Neagu Ionescu's "Musical Bouquet” printed in Bucharest at the Printing House of Church Books, in 1900 (page 226), but also in the old edition printed in Buzău in 1881 (pp. 239-240), this time without the author's note. We mention that this song was first translated or composed by Archimandrite Iosif Naniescu (Fig. 1)

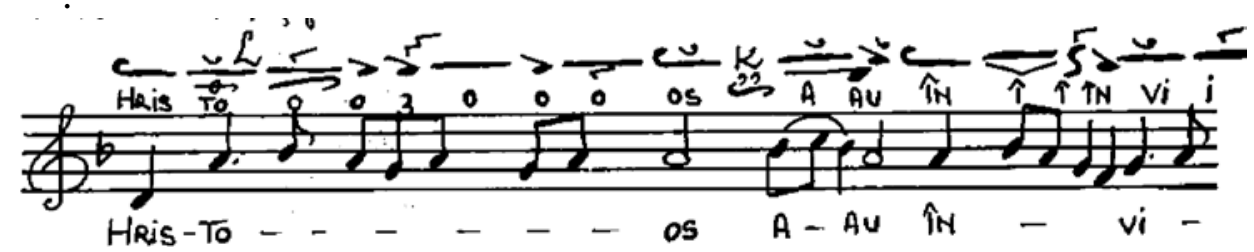

Fig. 1 “Hristos au înviat” (Iosif Naniescu) B.A.R. ms. rom. 4249 f. 188

An original Iosif autographed manuscript kept in the B.A.R. (Rom. ms. 3931) illustrates new chants signed by Iosif and dated “October 28, 1839". On the page 343 of the Manuscript we find the following songs, "At the Ordination, Mode VII ga, To the Holy Martyrs" (two forms, o.n.), "Glory to Thee, O Lord, Jesus Christ”, Mode VII ke, "O Isaiah, dance for joy”, Second Mode di (large, o.n.), and Mode VII ga, "Worthy is...”, with reference to page 
334: "written in 28 October 1839 in Buzău, by Iosif Nani(a)" (signed, o.n.). We also find these songs signed similarly at page 345 in the same manuscript.

It is very interesting for the history of the Romanian psaltic music that, although the holy mystery of ordination into priesthood has existed for centuries in the Orthodox Church, the name of the author or translator of the melody of the troparia of ordination is still unknown. They are still in use in present liturgical practice. Today's musical publications (Moldoveanu, 2002, pp. 12-14; Uncu, 1947, pp. 168-169; Popescu-Pasărea, 1991, pp. 128-129) record them as such; their existence seems to be enough, without any mention of the author. They are mentioned as "traditional chants" which complicates contemporary musical research.

Archbishop Gherasim Safirin, who published the troparion in his “Sobornicariu...” (Bucharest, 1914, page 102) makes an argument related to the troparia on Mode VII, "Holy Martyrs" and "Glory to Thee": "Hearsay from the Greeks of Athens”. Next to the troparion, Mode V, "O Isaiah, dance for joy", he offers another important statement: "A remake of the composition of Rev. Nectarios from the Holy Mount”. Hence, it is to Nectarios the Romanian, the Protopsalt of the Holy Mount, Iosif Naniescu's contemporary, that the troparion Mode V heirmoic, "O Isaiah, dance for joy", translated into his national language, is assigned. For a good period of time, the troparia Mode VII were also in use in an oral version in Greek, as it was the trend of that age.

Looking back into music history, we also find these troparia published by Ioan Zmeu in his "Music Book of Katabasia” (Buzău, 1907) on page 102, and attributed to the interpretation of the former Bishop of Argeș, Gherasim Timuș: "The troparia we sing at the services of the holy matrimony and the ordination into priesthood just as His Eminence, Bishop of Argeş, D.D. GherasimTimus, sings them". The same troparia are also published by Neagu Ionescu, the church music teacher from the Buzău Seminary School, in the two editions of the "Musical Bouquet", one published in Bucharest, in 1900, (pp. 152-153), and the other in Buzău, in 1881 (pp. 134-135), translated and signed by him. Interestingly, the chants sung by Gherasim Timus (and published by Ioan Zmeu in 1907) are similar to Neagu Ionescu's, with slight differences of conversion of some melodic formulas. The same troparia are published by Dometie Ionescu in his "Anthology" (Bucharest, 1898), at pages 72-73, perhaps not accidentally after Iosif Naniescu's Great Responses (pp. 70-71) without any specification of the author. The troparia published by Ştefanache Popescu (Bucharest, 1860), in his book "Church Music Anthology”, pp. 45-46, are similar. In "The Order of the Holy and Divine Liturgy" by Anton Pann (Bucharest, 1847, pp. 37-39), we encounter these troparia with the following note: “... at the ordination of deacons or priests, we sing these troparia."

Among some other novel chants signed by Metropolitan Iosif, the autograph manuscript B.A.R. Rom. ms. 3931, shows these ordination troparia 
at pages 343 and 345, signed by Iosif in October 28, 1839, that is, 75 years before Bishop Gherasim Safirin, 68 years before Ioan Zmeu, 59 years before Dometie Ionescu, 42 years before Neagu Ionescu, 21 years before Professor Ştefanache, and 8 years before Anton Pann.

We find the second version of the troparia, Mode VII, "Holy Martyrs", and "Glory to Thee, O Lord" (BAR, p. 3931 f. 343), published (without mentioning the author, o.n.) at pages 17 and 18, in "First Volume of the Anthology", published by "Nectarios the Protopsalt" Association (Bucharest, 2007), by the work of the church chanters of the St. Gregory Palama Church in Bucharest, Gabriel Duca and Valentin Gheorghe. We mention that these chants published at pages 17-18 under the title "another series of chants, Mode 7" are versions of Iosif Naniescu. (Fig. 2-7)

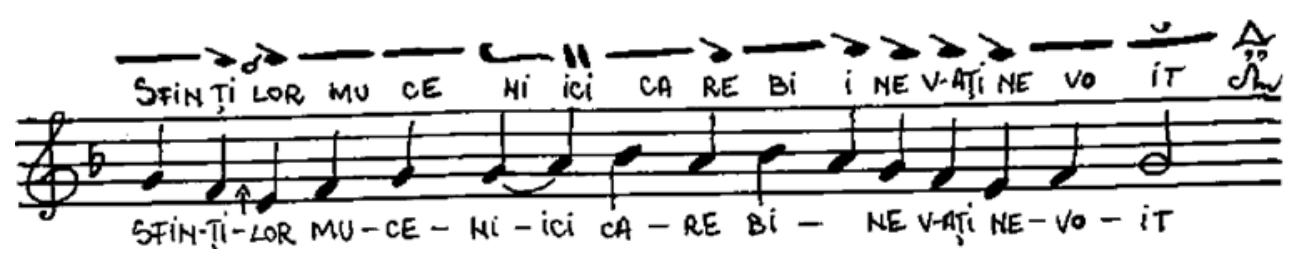

Fig. 2 "Sfinților Mucenici” (Iosif Nania 1839)

B.A.R. ms. 3931 f. 343, 344 glas VII ga

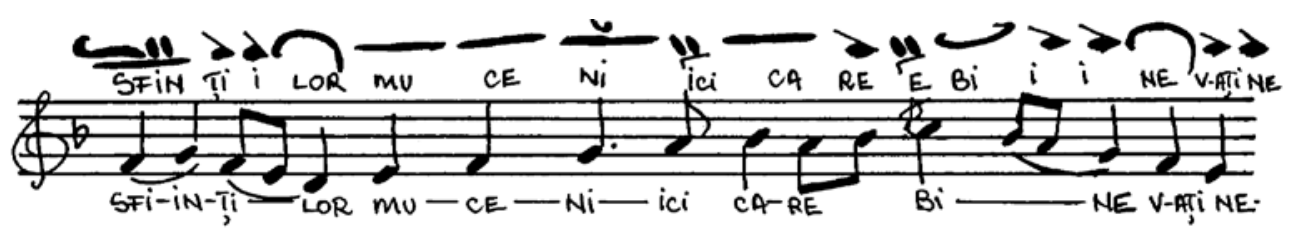

Fig. 3 "Sfinților Mucenici” (other variant by Nania, 1839)

B.A.R. ms. rom. 3931 f. 343

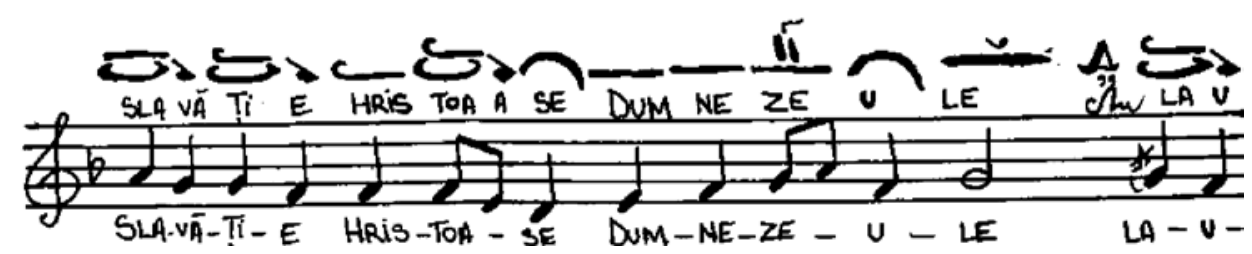

Fig. 4 "Slavă Ție Hristoase Dumnezeule...” (Iosif Naniescu, 1839)

B.A.R. ms. rom. 3931 f. 343 


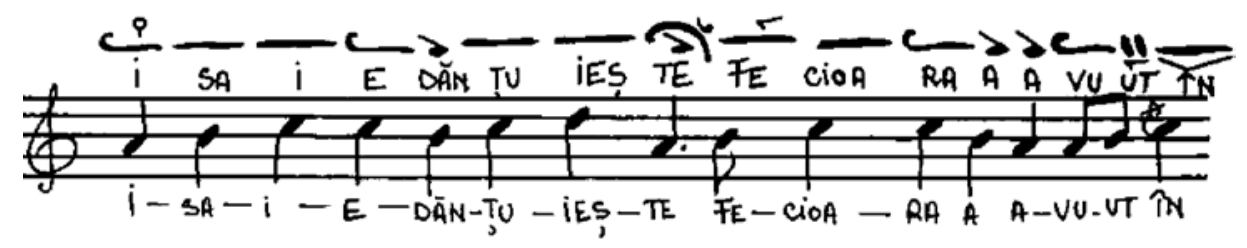

Fig. 5 “Isaie dănțuiește” (Iosif Naniescu, 1839)

B.A.R. ms. rom. 3931 f. 344, Glas V tetrafon ke

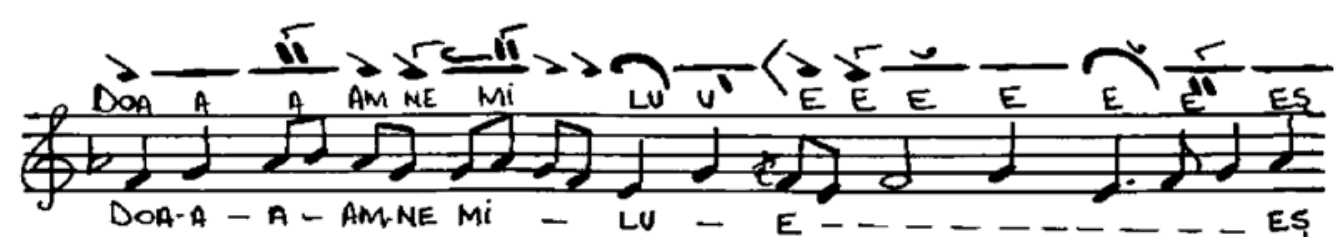

Fig. 6 "Doamne miluiește” (de Iosif Naniescu 1839)

B.A.R. ms. rom. 3931 f. 344 Glas II di

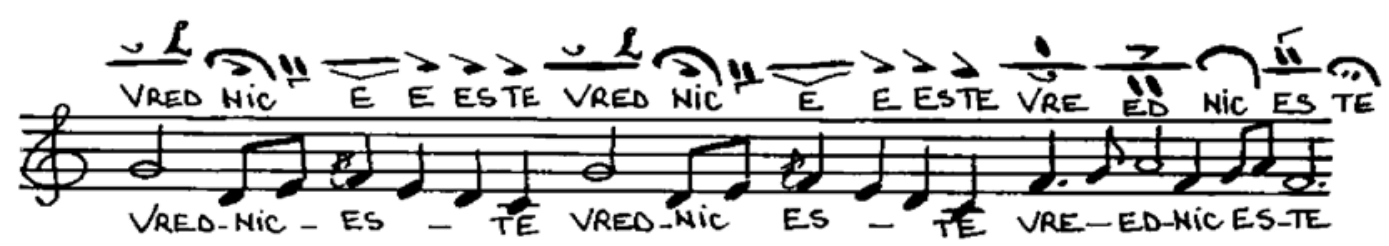

Fig. 7 "Vrednic este” (Iosif Naniescu, 1839)

B.A.R. ms. rom. 3931 f. 344 Glas VIII ni

In 1861 Iosif Naniescu wrote the Great Responses of St. Basil’s Liturgy, the original chants identified in B.A.R. Rom. ms. 4249 f. 183, with the following note: “... At St. Basil the Great's Holy and Divine Liturgy, this second Mode of the chant was first sung and composed by St. John of Damascus, and later they were shortened by John the Sweet. Then, they were further shortened by John the Protopsalt as they are sung today in The Holy Church of God, and then they were translated in our Romanian language by Archimandrite Iosif Naniescu in the Găiseni Monastery, as we know them now. In the year 1861, Mode II, di, "It is meet and right”, f. 183v; "Holy, Holy, Holy", f. 185 "We Praise Thee". These beautiful responses can also be found in B.M.M.B; ms. no. 340 f. 189-194 and B.C.U.M.E. Rom. ms.- gr. II-71 f. 166. At the Holy Mount Athos we identify these answers in B.S.P. Rom.ms.24/54 f. 228v.

These chants have been preserved over time by writing or orally, according to Archimandrite Iosif's original formula, up to the protopsalt professor I. Popescu-Pasărea, who, in 1925, printed them with slight changes (shortening the formulas) on page 65 in "The Liturgy Book for the Chorus", 
without specifying the author of the original form. We mention Archimandrite Iosif Naniescu as author of these precious responses. We render here the two forms of the chant in order to lay stress on their paternity. (Fig. 8-9)

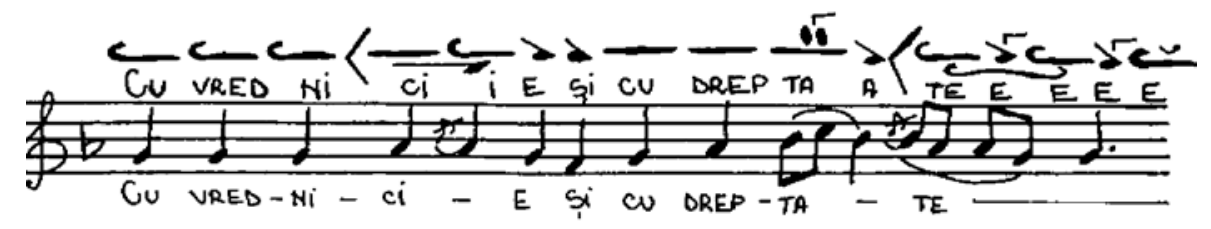

Fig. 8 “Cu vrednicie și cu dreptate” glas II di (Iosif Naniescu, 1861)

B.A.R. ms. rom. 4249 f. 183

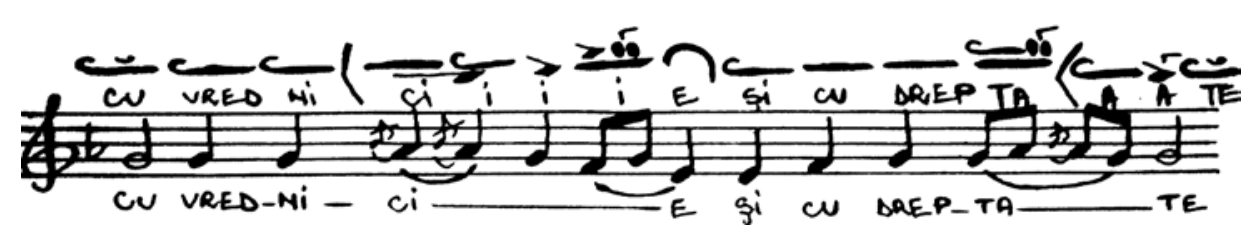

Fig. 9 “Cu vrednicie și cu dreptate” glas II di (I. Popescu-Pasărea) Liturghier de strană, București, 1925, p. 65

The three Stases of the Lamentations, which we find at page 7 in the B.A.R., Rom. ms. 4013, are truly original. The manuscript belonged to Metropolitan Joseph Naniescu's archive and was donated to the Romanian Academy after his death, which justify es the frequent pencil reinforcing that statement. The writing is similar to that of the autograph manuscript 3931, which also encourages the hypothesis that it was probably written by Iosif himself. An interesting thing is that, besides hieromonk Macarie's variant of the Lamentations, published in Buzău in 1836, there is also a short written version of the Stases of the Lamentations almost identical to those chanted nowadays (Fig. 10-12).

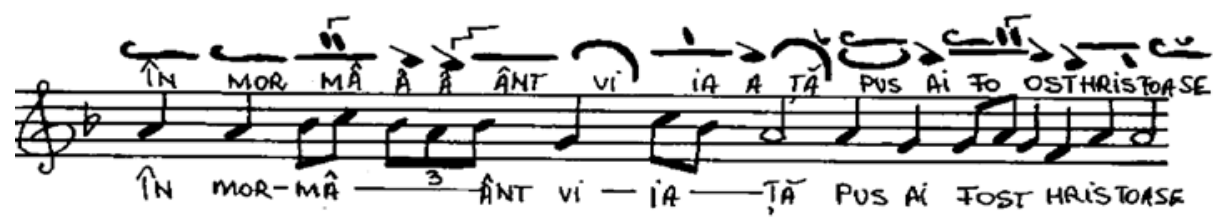

Fig. 10 "Prohodul Domnului...” (Iosif Naniescu)

B.A.R. ms. rom. 4013 f. 7 glas V pa, Starea I (other variant, o.n) 


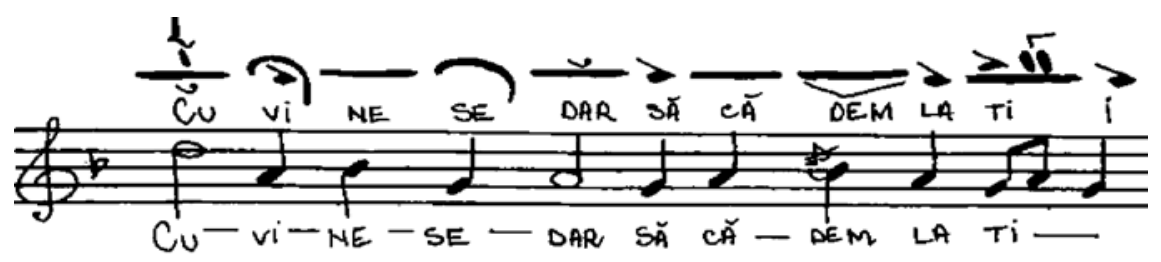

Fig. 11 "Prohodul Domnului...” (Iosif Naniescu)

B.A.R. ms. rom. 4013 f. 7 glas V pa, Starea II-a (other variant, o.n.)

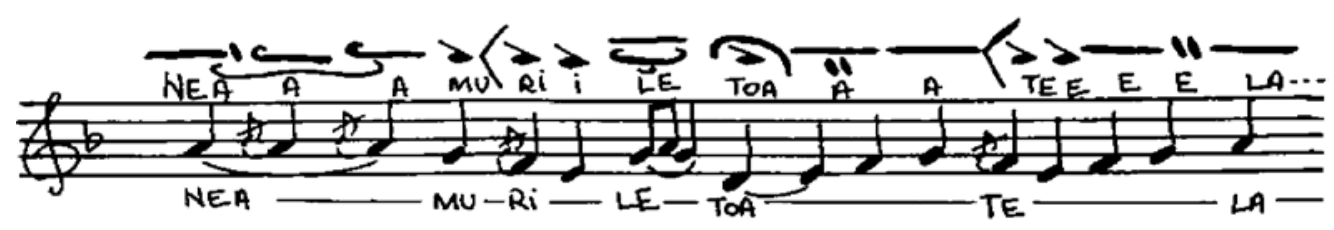

Fig. 12 "Prohodul Domnului...” (Iosif Naniescu)

B.A.R. ms. rom. 4013 f. 7 glas V pa, Starea III-a

Endowed with an exceptional voice, with an ambitus to the sound "mi" of the third octave, Metropolitan Iosif was nicknamed "the Nightingale of Argeş” when he was a pastor there (Poslușnicu, 1928, pp. 89-90). His interpretation is highlighted by Archbishop Evghenie Humulescu-Piteşteanul, who noted on the $5^{\text {th }}$ page of the "Synodicon of the Holy Diocese of Argeș" (ms. recently discovered in the Archbishopric Library of Arges, o.n.) while mentioning the great servants of the Romanian Orthodox Church, with whom he had the joy to serve: "Among them, there was shining Metropolitan Iosif Naniescu, venerable and zealous about the customs of the patriarchs, a gentle figure, unsurpassed master of psaltic music, and a famous chanter endowed with a warm and sweet voice...”

\section{Conclusions}

Iosif Naniescu sang in church all his life, just as he himself signed on manuscripts. By his compositional and translating style, he proved to be a true reference for other composers, and was often asked to correct and interpret musical prints. However, the Metropolitan saw only a part of his musical work printed in the collections of Anton Pann (1847), Professor Ştefanache Popescu (1860), George Ionescu (1878) - a disciple, teacher Neagu Ionescu (1881) and Ioan Zmeu (1892). This is one of monk Iosif's gestures of humility, who did not make use of his position to see his complete works published; he cared more for salvation than for glory, as Ghelasie Basarabeanu, the Archdeacon of the Arges Bishopric See noticed. This must have been one reason for which Iosif was not mentioned in some of the prints as the author of certain translations or compositions. Another reason may have been the notoriety of 
his compositions and translations that no longer needed attribution. Therefore, the present article comes to reinforce the paternity of his chants; it also represents a tribute to classical music of Byzantine tradition.

Iosif Naniescu took care that his disciples did not lack chants. He translated and composed for 64 years, since early childhood, starting at the age of only 15 years (1833) until 1897, five years before his passing to the Lord. In the last five years of his life, he was probably concerned rather with spiritual than material things, for he was known as a pious monk. The "Romanian Patericon” (a collection of stories of old monks' live sand teaching) presents rich material summing up the stories of his contemporaries, describing him as having led a holy life, full of good deeds. In this respect, Archimandrite Ioanichie Bălan (Bălan, 1998, pp. 474-482) reports a number of 40 events based on solid testimonies that tell us why Iosif Naniescu was granted the surname of "the holy" by the people (Vasilache, 1940, p. X).

His pure life, his deeds of mercy, his spiritual sayings and acts, his lofty life, his virtues, made Metropolitan Iosif a man loved by the people and considered to be the brightest hierarch of the Romanian Orthodox Church in the second half of the nineteenth century, immediately after Saint Calinic of Cernica.

\section{References}

Angelescu, C. C. (1982). Contribuții la biografia Mitropolitului Iosif Naniescu [Contributions to the biography of the Metropolitan Iosif Naniescu]. Mitropolia Moldovei și Sucevei, LVIII, 1-2, ianuarie-februarie, 53 - 69. Iași.

Bălan, I., Arhimandrit (1998). Patericul Românesc ce cuprinde viața și cuvintele unor sfinți și cuvioși părinți ce s-au nevoit în mânăstirile românești (secolele III-XX) [The Romanian Patericon comprising the life and words of some saints and monks from the monasteries of Romania], Ediția a-III-a. Galați: Episcopia Dunării de Jos.

Barbu-Bucur, S. Arhid. (2000). Manuscrise muzicale româneşti de la Muntele Athos. [Romanian musical manuscripts from Mount Athos]. Bucureşti: Editura Muzicală.

Barbu-Bucur, S., Catrina, C., (2013). [Protopsalți și Manuscrise de la Mănăstirea Cheia-Teleajen [Protopsalms and Manuscripts from Cheia Teleajen monastery]. București: Editura SemnE.

Bucescu, F. \& Catrina, C., Barnea, A. et. al. (2010). Catalogul manuscriselor de muzică sacră din Moldova-secolele XI-XX (I) [The catalogue of the manuscripts of sacred music from Moldova $-9^{\text {th }}$ and $10^{\text {th }}$ century (I). Iași: Artes.

Bucescu, F. (2009). Cântarea psaltică în manuscrisele moldovenești din sec. al XIXlea. Ghidul manuscriselor psaltice - Moldova, sec. XIX, volumul II [The psaltic chant in the Moldavian manuscripts from the $9^{\text {th }}$ century. The guide of the psaltic manuscripts - Moldova. XIX century, volume II]. Iași: Artes. 
Buzera, A. Al. (1999). Cultura muzicală românească de tradiţie bizantină din sec. al $X I X$-lea [Romanian musical culture of Byzantine tradition from the $9^{\text {th }}$ century]. Craiova: Fundaţia Scrisul Românesc.

Buzera, A. Al. (1999). Trei manuscrise de la B.C.U. „Mihai Eminescu” din Iași cu opera muzicală inedită a lui Ghelasie Basarabeanul [Three manuscripts from the "Mihai Eminescu" University Library of Iasi, regarding the original music works of Ghelasie Basarabeanul]. Byzantion, II, 70-71. Iași: Academia de Arte „George Enescu”.

Catrina, C. (2010, editor). Sebastian Barbu-Bucur, octogenar [Sebastian Barbu-Bucur, octogenarian]. București: Editura SemnE.

Duca, G. \& Gheorghe, V. (2007). Tomul întâi al Antologiei [The first tome of the Anthology]. București: Asociația Nectarie Protopsaltul.

Gașpar, I. (1982). Un manuscript de cântări bisericești [A manuscript of church chants]. Mitropolia Moldovei și Sucevei, LVIII, 1-2, ianuarie - februarie, 69-74. Iași.

Gavrilă, I. (2010) Muzica Bisericească în ținutul Vâlcii, Studiu Monografic [Religious music in the area of Valcea. Monography]. București: Editura Roza Vânturilor.

Gheorghiță, N. (2012). De la neumă la interpretare sau despre procesul compoziţional în muzica bizantină. [From neume to interpretation or about the compositional process in the Byzantine music]. Analele Putnei, VIII, 389-408. Putna: Centrul de Cercetare și Documentare Ștefan cel Mare al Sfintei Mănăstiri Putna.

Harbuzaru, M. (2012). Manuscrisele psaltice de la Mănăstirea Sinai [The pasltic manuscripts from Sinai Monastery]. București: Editura Cuvântul Vieții.

Ionescu, G. C. (2003). Muzica Bizantină în România. Dicționar Cronologic [The Byzantine music in Romania. Chronological Dictionary]. București: Sagittarius.

Ionescu, N. (1881). Buchetul muzical ce conține cântările indispensabile unui cântăreț tot timpul anului..., culegere după diferiți autori și compoziții originale de N(eagu) Ionescu [A musical bouquet of chants indispensable to a singer throughout the year... collection of different authors and original compositions by Neagu Ionescu]. Buzău.

Ionescu, N. (1900). Buchetul muzical [Musical bouquet]. București: Tipografia Cărților Bisericești.

Isăroiu, I. (2008). Ghelasie Basarabeanu personalitate marcantă a muzicii bizantine [Ghelasie Basarabeanu - significant personality of the Byzantine music]. Pitești: Universitatea din Pitești.

Moise, B. (2004). Cultura muzicală românească de tradiţie bizantină, zona BuzăuVrancea, sec. al XIX-lea (teză de doctorat nepublicată) [Romanian musical culture of Byzantine tradition, Buzau-Vrancea area, the $9^{\text {th }}$ century (unpublished doctoral paper)]. Universitatea Naţională de Muzică, București. 
Moldoveanu, N. (2002). Cântări la Sfintele Taine și la Ierurgii și alte cântări religioase [Songs for the Holy Mass and for Hierourgy and other religious chants]. București: Institutul Biblic și de Misiune al Bisericii Ortodoxe Române.

Nastasă, I.-G. (2010). Manuscrise muzicale inedite (secolele XIX-XX) [Original musical manuscripts]. Invățământul Universitar Vocațional la Ceas Aniversar - 2010. Studii și cercetări [The vocational university education's celebration - 2010. Studies and research], (pp. 500-519). Iași: Doxologia.

Neacșu, G. (2006). Manuscrise copiate de protopsalți și muzicieni argeșeni din Fondul Direcției Județene Vâlcea a Arhivelor Naționale [Manuscripts copied by protopsalts and musicians of Argeș from the National Archives of the Vâlcea county]. Glasul Bisericii, 5-8, mai-august, 408-412.

Pann, A. (1847). Rânduiala Sfintei și Dumnezeeștei Liturghii [The layout of the Holy and Godly Liturgy]. București: Tipografia proprie [own printing house].

Pătraşcu, C. (2010). Fondul de manuscrise muzicale româneşti din Biblioteca Sfântului Sinod (lucrare de disertaţie nepublicată) [The corpus of Romanian musical manuscripts from the Library of the Holy Synod (unpublished dissertation)]. Universitatea Naţională de Muzică, Bucureşti.

Popescu-Pasărea, I. (1908). Cântările Sf(intei) Liturghii scrise pentru corurile sătești, după melodiile bisericești-tradititonal [The songs of the Holy Liturgy written for the villages' choirs after traditional church chants]. București: Institutul de Arte Grafice Carol Göbl.

Popescu-Pasărea, I. (1925). Liturghierul de strană [The lectern reader]. București: Tipografia Cărților Bisericești.

Popescu-Pasărea, I. (1991). Liturghier de strană [The lectern reader]. Curtea de Argeș: Episcopia Argeșului.

Popescu, Ș. (1860). Colecțiuni de cântări bisericești [Collections of church chants]. București: Tipografia Nifon Mitropolitul.

Posluşnicu, M. Gr. (1928). Istoria muzicei la Români [The music history in Romania]. București: Cartea Românească.

Safirin, G. (1908). Culegere de cântări bisericeşti [A collection of church chants]. Bucureşti: Tipografia Cărţilor Bisericeşti.

Secară, C. (2006). Muzica bizantină - doxologie şi înălţare spirituală [The Byzantine music- doxology and spiritual elevation]. Bucureşti: Editura Muzicală.

Scurtu, C. D. (2011). Iosif Naniescu privighetoarea Argeșului (1818-1902). Păstorul Ortodox [Iosif Naniescu the nightingale of Arges (1818-1902). The Orthodox Sheperd]. 253-284. Curtea de Argeș: Arhiepiscopia Argeșului și Muscelului.

Scurtu, C. D. (2007). Noi mărturii despre arhiereul-protopsalt Evghenie HumulescuPiteşteanu (1870-1931) [New confessions about the protopsalt Evghenie Humulescu Piteşteanu (1870-1931)]. Byzantion-Romanicon, VII, 281-291. Iaşi: Artes. 
Uncu, A. V. (1947). Antologhionul [Antologhyon]. București: Tipografia Cărților Bisericești.

Vasilache, V. (1940). Iosif Naniescu, strălucit mitropolit al Moldovei [Iosif Naniescu. Brilliant Metropolitan of Moldova]. Mănăstirea Neamţ.

Vasile, V. (1994). Iosif Naniescu - reprezentant de seamă al muzicii psaltice [Iosif Naniescu - significant representative of the psaltic music]. Muzica, new series, IV (16), 2, 99-111. București: UCMR.

Vasile, V. (1994). Iosif Naniescu - reprezentant de seamă al muzicii psaltice [Iosif Naniescu - significant representative of the psaltic music]. Muzica, new series, IV (16), 4, 127-137. București: UCMR.

Vasile, Vasile, (2007) Tezaur muzical românesc din Muntele Athos [Romanian musical treasury from the Mount Athos]. vol. I-II. București: Editura Muzicală.

Zmeu, I. (1907). Catavasierul muzical, Tomul Utreniei și Tomul Liturghiei [The musical hymn book. The tome of Matins and the Tome of the Liturgy]. Buzău: Imprimeria Alexandru Georgescu. 